\title{
Research Paper A study on performances of selected e-NAM linked regulated markets in Tamil Nadu
}

\author{
S. Padma Rani, A. Vidhyavathi and Aiswarya Sabu
}

See end of the paper for authors' affiliations

Correspondence to :

S. Padma Rani

Department of Agricultural Economics, Tamil Nadu Agricultural University, Coimbatore (T.N.) India Email: padmaranisenthil@ yahoo.com

Paper History :

Received : 14.06.2020;

Revised : 16.07.2020,

Accepted : 18.08 .2020
ABSTRACT : National Agriculture Market (NAM) is an electronic trading portal which networks the existing APMC markets to create a unified national market for agricultural commodities. In Tamil Nadu, about 278 regulated markets are functioning under 21 market committees. Of these eighty regulated markets have been brought under the e-NAM system in two phases during 2017-2020. At present most of the markets are connected with e- NAM portal. The present study was conducted in Dindigul, Annur, Gobichettipalayam, Anaimalai and Tiruppur regulated markets. The major objectives of the study are : to review the progress in implementation of e-NAM in selected regulated markets of Tamil Nadu, to assess the level of awareness about e-NAM among farmers and traders, to study the willingness to participate in e-NAM trading by farmers and traders and to study the benefits and constraints perceived by farmers traders and market officials in adoption of e-NAM. Primary data was collected from 60 farmers and 30 traders in Gobichettipalayam and Anaimalai regulated markets. Binary Logit regression model was used to know the willingness to participate in e-NAM marketing by farmers and traders. Analysis of results shows that the about 30 per cent registered farmers are unaware of e-NAM. And majority of them are not aware of the e-NAM process completely. The major factor influencing the participation of farmers in e-NAM is remunerative price. The major factors influencing the traders participation is influenced by the level of IT knowledge. Constraints faced by farmers in the study markets is delayed payment (95\%) followed by inadequate infrastructural facilities. Farmers lack computer skills and faces difficulty in understanding e-NAM process.

KEY WORDS : E-trading, Regulated market, Assaying, Logit regression

How To Cite This PAper: Rani, S. Padma, Vidhyavathi, A. and Sabu, Aiswarya (2020). A study on performances of selected e-NAM linked regulated markets in Tamil Nadu . Internat. Res. J. Agric. Eco. \& Stat., 11 (2) : 198-204, DOI : 10.15740/HAS/IRJAES/11.2/198-204. Copyright@2020:Hind Agri-Horticultural Society. 